\title{
Da criação de um lugar
}

\author{
Nísia Floresta: a primeira \\ feminista do Brasil.
}

UMA DUARTE, Constância (Org.).

Florianópolis: Mulheres, 2005. 143 p.

Dionísia Gonçalves Pinto. Nome de batismo da mulher públic a Nísia Floresta Brasileira Augusta. Mulherpública no sentido em que Nísia se coloca. Até muito pouco tempo, o termo era sinônimo de mulher da vida, de prostituta. O lugar da mulher de 'bem' era sem dúvida na esfera privada. Nísia chama a atenção para a importância, a necessidade, a ind ispensabilida de da mulher no campo que lhe foi poupado a té então.

Nasceu em 1810 no interior do Rio Grande do Norte. Viveu do norte ao sul do país. A partir de 1849 passou a transitar ta mbém pela Europa, principalmente por Paris. Casou-se a primeira vez a os treze anos, mas se separou logo. Porvolta de 1828, uniu-se a Manuel Augusto de Faria Rocha, com quem teve três filhos, dos qua is um morreu prematuramente. Manuel Augusto morreu logo após o nascimento do terceiro filho. 0 nome Augusta, que adotara em seu pseudônimo, é uma homenagem ao seu companheiro. Teve uma longa vida e morreu, em 1885, de pneumonia. Longa também é a lista de suas public ações.

Esse livro organiza do por Constância Lima Duarte, professora de Literatura Brasileira na UFMG e responsável pela publicação de outras obras relacionadas a Nísia Floresta, é composto por excertos da obra dessa feminista. A public ação traz, a lém dos excertos, uma apresentação, uma cronologia da vida e obra de Nísia, e um levantamento bibliográfic 0 .

A apresentação, escrita por Constância, apresenta muito bem e contextualiza a vida e obra dessa feminista com sua época. Os excertos são divididos a partir de suas public ações e pela ordem em que foram publicados inicialmente. Foram três as obras escolhidas: Direitos das mulheres e injustiça dos homens, Opúsculo humanitário e Cintilações de uma alma brasileira. Essa última, public ada orig ina Imente em ita lia no em 1859, só foi tra duzida e public ada em português em 1997. 
O livro Direito das mulheres e injustiça dos homens foi escrito a partir de uma antropofagia libertária, segundo Constância Duarte. É a primeira obra de que se tem notícias no Brasil de problematizar o espaço da mulher e os direitos que the interessam. Em uma tradução livre do livro Vindic ations of the Rights of Woman, de Mary Wollstonec raft, Nísia inspirou-se ta mbém na leitura de outros autores como Poula in de La Barre, Sophie e Olympe de Gouges. Antecipou a lógic a antropofágica de Oswald de Andrade: deglutiu o pensamento europeu e o re-inventou no contexto brasileiro.

Nísia Floresta acreditava que as necessidades da mulher no Brasil a inda estavam um pouco distantes do que propunham as feministas de além-mar, considerando que no Brasil as mulheres ainda eram, em sua grande maioria, a nalfa betas.

A educação apresentava um pape fundamental na obra de Nísia, que usa va a lógic a utilitarista para defender o seu ponto de vista: a posição que cada um deveria ocupar na sociedade, com relação a o seu prestígio e respeito, deveria ser medida de acordo com a sua utilidade na sociedade. Nesse sentido, segund o ela, a mulher seria o bem mais precioso, poisantes de tudo criava e educava aquelesque viriam a ser médicos, juízes, govemantes, enfim, homens com importantes papéis para a sociedade.

Se a mulher possuía a capacidade para exercerum papel tão nec essá rio e fundamental, era um erro tremendo afastá-la da vida pública, poupando-Ihe a educação devida. Nísia não tinha a menor dúvida do quão importante era a participação da mulher em espaços dominados exc lusivamente peloshomens. Defendia que, “Em um Estado tranqüilo e bem regido, a maior parte dos homens são inúteis em seus ofícios, e inútil toda a sua autoridade, mas as mulheres não deixarão jama is de ser necessárias enquanto existirem homens e estes tiverem filhos" (p. 72).

Não questionava a ordem vigente, mas o lugar da mulher, sua posição, sua importância dentro dessa ordem. Acreditava que o papel da mulher deveria ser mais prestigiado, e não considerado baixo, desprezível, ou menos importante. Insistia em um melhor tra ta mento e melhores condições, pois só assim a mulher poderia atuarainda melhor na sociedade.

Em um dado momento de Direitos das mulheres e injustiça dos homens, pensando no lugar de merecimento da mulher e na importância que não lhe é a tribuída, acaba por desmontar toda a lógica da sociedade que defende. Sem querer, Nísia faz uma a nálise sucinta, porém completamente destrutiva, do lugar dos juízes, mag istra dos, ofic ia is, sold a dos e príncipes, não como fez anteriormente, coloc and o um Esta do hipotétic o "tranqüilo e bem regido", mas afirmando a inutilidade desses cargos para a vida de um homem (ou mulher). Se antes elogiara a função de govemabilidade de príncipes e ministros, marca que, se esses "se sacrificam a lgumas vezes pelo bem públic $0, a$ a mbição é o únic o móvel, é para a dquirir poder, riquezas e esplendor, que eles o fazem" (p. 73).

No entanto, logo volta a trás em suascrític as:

"[...] fiquem as coisas no seu mesmo estado: eu pretendo somente fazerver que o meu sexo não é tão desprezível como os homens querem fazer crer" (p. 81). Afinal, nã o está interessa da em uma mudança radical, e também o deixa claro quando elogia o papel da mulher como domesticadora dos homens, falando de como esta se presta tão bem à função de amansaras crianças, para que estas possam servir adequadamente à sociedade.

Quando publica o Opúsculo humanitário, em 1853, Nísia Floresta já havia percomido grande parte da Europa. Talvez porisso essa obra pareça contextua lizar ma is intema ciona Imente a história e o movimento das mulheres, a partir de onde coloca de modo mais enfático a necessidade de se pensara questão das mulheres no Brasil de uma nova forma. Como já havia mencionado em obras anteriores, enquanto se falava em diversos direitos das mulheres na Europa, aqui a preocupação era ainda com a educação mais elementar.

Além de ter escrito diversos livros e artigos sobre a temática da mulher, Nísia era também poetisa e romancista. Em Cintilações de uma a Ima brasileira, Nísia adota na introdução de seu texto intitulado "A Mulher" uma linguagem mais literária. Como aponta Constância, "O texto apresenta três momentos bem definidos. Inicia como se fosse uma ficção; transmuda-se em a utêntica crônica com anotações sobre o comportamento humano; e termina emitindo reflexões de cunho filosófic o com nítid o propósito didático" (p. 35).

Nessa obra, Nísia sai um pouco do contexto brasileiro para fazer uma crític a às práticas das mulheres francesas, principalmente as burguesas. Em nome de certos valores, que consideravam degradantes as relações entre mães e filhos, legitima vam um desc uido total com as crianças francesas, que eram mandadas para amas no campo e esquecidas. As que sobreviviam voltavam para casa, para então receber a 
educação a dequada. Essa situação a caba abrindo para a problematização da noção de natureza matema.

Apesar de defender em quase toda sua obra a superioridade das mulheres com relação aos homens, chama a a tenção para a horizontalidade, quando aponta para o companheirismo que deve existir entre os dois:

Se a maior parte dos homens não procurasse na santa união do matrimônio um comércio que os a vilta, ou um meio para teruma legítima prole; se uma mulhernão procurasse aímuitas vezes senão uma condição no mundo, ou uma mal interpretada liberdade que a libere de certos preconceitos; se um e outra, antes de se ligarem para sempre houvessem por bem entenderem-se entre eles, se estudar, se conhecer e se amar, a doce união do matrimônio, tão caluniada, tão profanada e tantas vezes fracassa da, seria enfim o non plus ultra da humana felicidade (p. 132).

Mesmo em defesa da mulher, não é difícil perceberque o pensa mento de Nísia a inda está muito permeado pelo pensamento de sua época, sendo possível notar um tom conserva dorem seus discursos. Na verdade, ele é inovadorno que se refere às práticas nacionais $e$, sem dúvida, o pensamento de Nísia estava muito à frente da grande maioria dospensa dores brasileiros de sua época. Talvez o fato de ter vivido em muitos lugares tenha contribuído para uma maior flexibilidade de suas idéias. Porém, defende também que a mulher deve ter melhores condições para melhor servir no seu papel de mãe e esposa dedicada.

Na obra de Nísia, também chama a atenção o fato de ela sertalveza primeira mulher a adotar um sentido de gênero para o sexo feminino. Essa percepção é muito sensata, a inda ma is se pensa mosque o gênero é uma ca tegoria de classificação positivista, e nada mais de acordo nesse sentido, pois Nísia defendia noções positivistas de ordem e progresso sob um ponto de vista ma is liberal. Não parece totalmente fora de contexto lembrarque, a pós ter cursa do a ulas do positivista Augusto Comte, trocou uma série de cartas com ele. Afinal, os dois não estavam tão a partados em suas linhas de pensamento.

Porém, volto a pensar na maneira como Nísia se coloca perante a vida, na relação que parece tertido com o segundo marido e com os seus filhos, no fato de sua filha ter se tomado sua companheira nas viagense traduzido diversas de suas obras, a o invés de teradotado oscaminhos que the seriam esperados.

$\mathrm{Na}$ forma como Nísia escreve não tra nspa rece nenhum rancor com rela ção às sua s experiências. Parece-me que suas práticas e experimentações de vida, ainda mais em tal época, tiveram uma contribuição muito mais interessante do que os seus discursos propriamente ditos. Constância Duarte recorre a Gilberto Freyre quando este percebe que

Nísia Floresta surgiu - repita-se, como uma exceção escandalosa. Verdadeira machona entre as sinhazinhas dengosas do meado do século XIX. No meio de homensa dominarem sozinhos todas as a tivid a des extra-d oméstic as, as próprias baronesas e viscondessas mal sabendo ler e escrever, as senhoras mais finas soletrando a penas livros devotose novelas que eram histórias do Troncoso, causa pasmo ver uma figura como a de Nísia (Epígrafe, p. 13).

É dessa forma que se abre a a presentação do livro. A partir dessas palavras, não é difícil compreendera obra ma is funda mental de Nísia. A obra que inscreveu nos corpos daqueles com que se relacionara, que estava além de seus disc ursos. Muito ma is simples em sua forma. Sem a profundidade de seus textos, mas com a intensidade de sua vida.

Eliane Knom

Pontifícia Universidade Católica de São Paulo 